DOI: https://doi.org/10.15407/techned2018.05 $: \underline{069}$

\title{
STUDY OF CHANGED MAIN FLUX REACTANCE OF SQUIRREL-CAGE INDUCTION MOTORS USING FIELD ANALYSIS OF THEIR STARTING CHARACTERISTICS
}

Journal

Publisher

ISSN

Issue

Pages
Tekhnichna elektrodynamika

Institute of Electrodynamics National Academy of Science of Ukraine 1607-7970 (print), 2218-1903 (online)

No 5, 2018 (September/October)

$69-72$

\section{Authors}

\section{O.M. Popovych*, I.V. Golovan**}

Institute of Electrodynamics National Academy of Sciences of Ukraine,

pr. Peremohy, 56, Kyiv, 03057, Ukraine,

e-mail: popovich1955@ukr.net

* ORCID ID : http://orcid.org/0000-0002-9238-5782

** ORCID ID : http://orcid.org/0000-0002-5250-6981

The regularities in the change of the main flux reactance of squirrel-cage induction motors as slip functions are studied by quasi-3D field analysis to determine the equivalent parameters of equivalent circuit. The comparative analysis of the design conditions and calculated starting characteristics of the motors is carried out. As shown, the use of electromagnetic parameters which are equivalent to the parameters obtained by field model gives more high accuracy of calculation. As grounded, the coefficient of change of equivalent air gap is available and expedient to be taken in account for investigation of the motors. References 8 , figures 2 , table 1. 
Key words: induction motors, parameters of the equivalent circuit, field model, main flux reactance, start.

Received: 05.03 .2018

Accepted: 10.05 .2018

Published: 16.08 .2018

\section{References}

1. Kravchik A.E., Shlaf M.M., Afonin V.I., Sobolenska E.A. Induction motors 4A series. Moskva: Energoatomizdat 1982. 504 p. (Rus)

2. Radin V.I., Londin Y., Rozenknop V.D. The unified series of asynchronous motors Interelektro. Moskva: Energoatomizdat, 1990. 416 p.(Rus)

3. Vaskovskyi Yu.M., Tytko O.I., Makeykin I.S., Kravchuk V.A. Diagnosis of induction motors based on analysis of starting. Tekhnichna Elektrodynamika. 2017. No 3. Pp. 58-64. (Ukr) 4. Milykh V.I., Polyakova N.V. Harmonious analysis of electromagnetic sizes three-phase winding of stators of turbogenerator on basis classic and numeral field methods. Tekhnichna Elektrodynamika . 2013. No 3. Pp. 40-49. (Ukr)

5. Verbovoy P.F. Experimental definition of parameters of asynchronous short-circuited engines. Tekhnicheskaia Elektrodynamika. 1983. No 1. Pp. 79-85. (Rus)

6. Popovych O.M., Golovan I.V. Refinement of analysis operation of induction motors as part electromechanical systems using equivalenting field models using electrical circuits. Tekhnichn a Elektrodynamika

. 2014. No 5. Pp. 113-115. (Ukr)

7. Popovych O.M., Golovan I.V. Definition of parameters of an equivalent circuit of an asynchronous motor by results of the field analysis. Pratsi Instytutu Elektrodynamiky Natsionalnoi Akademii Nauk Ukrainy 2012. No 31. Pp. 38-48. (Ukr)

8. Bibik O.V., Popovych O.M., Shevchuk S.P. Power effective modes electromechanical system of pump installation of the multistorey building. Tekhnichna Elektrodynamika. 2016. No 5. Pp. 38-45. (Ukr) 
PDF 